\title{
Analisis Kausalitas Inflasi dan Jumlah Uang Beredar di Indonesia Periode Tahun 2000.1-2014.4
}

\author{
Afrizal $^{*}$ \\ Universitas Tanjungpura Pontianak/ Fakultas Ekonomi dan Bisnis
}

\begin{abstract}
There is often a debate about causality between money supply and inflation. The purpose of this study is to analyze the causality, whether the money supply affects inflation or vice versa. Analytical tool used is unit root test, integration degree test, causality test with granger causality technique and cointegration approach. The result of unit root test data is not stationary, after test of stationary data continued at level 1 (first difference). The result of granger causality test with lag 12 indicates that the money supply has an effect on inflation rate in Indonesia, and vice versa means there is a mutual relationship. And based on Johanson's cointegration test shows that mutual cointegration means having long-term equilibrium relationship as desired by the theory.
\end{abstract}

Keywords: inflation, money supply, granger causality, cointegtration.

\section{PENDAHULUAN}

Inflasi merupakan salah satu variabel makroekonomi yang sangat ditakuti oleh setiap perekonomian, Namun eksistensinya masih tetap dibutuhkan bagi pertumbuhan ekonomi suatu negara, dan yang menjadi pertanyaan adalah seberapa besar inflasi tersebut yang masih dapat menunjang pertumbuhan ekonomi. Oleh karena itu pemerintah dan bank sentral setiap tahun dalam setiap menyusun Anggaran Pendapatan Belanja Negara (APBN) selalu berhati-hati dalam menetapkan tingkat inflasi, karena setiap penetapan tingkat inflasi maka konsekuensinya adalah mampukan pemerintah tersebut mencapai tingkat pertumbuhan yang diinginkannya.

Inflasi secara definitif dapat diartikan suatu keadaan dimana meningkatnya hargaharga secara umum dan terus menerus yang berhubungan dengan mekanisme pasar, artinya konsumsi masyarakat yang cenderung naik dan kelebihan likuiditas di pasar bahkan dapat sebagai akibat dari macetnya saluran distribusi. Inflasi dapat juga dikatakan sebagai proses menurunnya nilai mata uang secara terus menerus, yang dapat menyebabkan meningkatnya persediaan uang, yang sering dianggap penyebab naiknya harga, hal ini menunjukkan bahwa adanya indikasi mengenai hubungan fungsional antara jumlah uang beredar dengan tingkat harga.

\footnotetext{
"Korespondensi: Afrizal, Jurusan Ilmu Ekonomi, Fakultas Ekonomi dan Bisnis, Universitas Tanjungpura, Jalan Prof. DR. H. Hadari Nawawi, Pontianak 78124, Indonesia. Email: afrizal@ekonomi.untan.ac.id
} 
Dalam teori dan kajian empiris sering muncul perdebatan mengenai keterkaitan hubungan antara tingkat harga dan jumlah uang beredar. Apakah jumlah uang beredar dipengaruhi oleh harga atau sebaliknya. Sebagai contoh adalah kebijakan moneter moneter yaitu kebijakan uang ketat atau Tight Money Policy, yang bertujuan untuk memelihara kestabilan harga, hal ini menunjukkan bahwa variabel harga adalah target.

Secara umum kita dapat menyatakan bahwa suatu perekonomian dalam keadaan seimbang, tingkat harga dipengaruhi oleh jumlah uang beredar. Ditegaskan oleh Mankiw (2003), keeratan hubungan tingkat harga (inflasi) dan jumlah uang beredar tidak dapat dilihat dalam jangka pendek. Teori inflasi ini bekerja paling baik dalam jangka panjang.

Granger (1988) menyatakan bahwa hubungan kausalitas antara dua variabel dipengaruhi oleh perilaku data dan apakah keduanya berkointegrasi atau tidak. Fokus dalam penelitian ini adalah pengguanaan dua macam uji, kausalitas dan pendekatan kointegrasi. Uji kointegrasi digunakan untuk melihat apakah hubungan keseimbangan atau jangka panjang antar variabel sesuai dengan teori atau tidak.

Berdasarkan uraian di atas, maka penelitian ini bertujuan untuk mengetahui hubungan pengaruh yang sebenarnya antara jumlah uang beredar dan tingkat inflasi di Indonesia selama kurun waktu 2000.1-2014.4. Dengan diketahuinya arah dari hubungan tersebut, diharapkan pemerintah dapat mengambil kebijakan lebih efisien, disamping pengembangan ilmu dan pengajaran.

\section{KAJIAN LITERATUR}

\subsection{Teori Inflasi}

Inflasi adalah kecenderungan kenaikan harga barang atau jasa secara terus menerus dan kenaikan tersebut meluas ke seluruh sektor perekonomian yang lain karena ketidakseimbangan arus uang dan barang yang tersedia. Biasanya angka inflasi ditunjukkan dengan persentase. (Boediono, 2000: 161). Inflasi adalah proses kenaikan harga-harga umum secara terus-menerus selama periode tertentu, mempengaruhi individu, pengusaha dan pemerintah. Inflasi secara umum dianggap sebagai masalah penting yang harus diselesaikan dan sering menjadi agenda utama politik dan pengambil kebijakan (Miskhin, 2010: 13).

Menurut Mankiw (2003), keeratan hubungan inflasi dengan jumlah uang beredar tidak dapat dilihat dalam jangka pendek. Teori inflasi ini bekerja paling baik dalam jangka panjang, bukan dalam jangka pendek. Dengan demikian, hubungan antara pertumbuhan uang dan inflasi dalam data bulanan tidak akan seerat hubungan keduanya jika dilihat selama periode 10 tahun.

Setiap perekonomian pasti mengalami inflasi, yang menjadi pertanyaan kita adalah mengapa inflasi itu terjadi, berbahayakah inflasi tersebut?. Ada beberapa teori 
yang membahas tentang inflasi antara lain: teori kuantitas, Teori Keynes dan teori struktural.

1. Teori Kuantitas dari kaum klasik, berpendapat bahwa tingkat harga ditentukan oleh jumlah uang beredar, harga akan naik jika ada penambahan jumlah uang beredar, dengan asumsi jumlah barang yang ditawarkan tetap, sedangkan jumlah uang ditambah menjadi dua kali lipat, maka cepat atau lambat harga akan naik menjadi dua kali lipat.

2. Teori J. M.Keynes : Keynes melihat bahwa inflasi terjadi karena adanya keserakahan dari suatu kelompok masyarakat yang ingin memanfaatkan lebih banyak barang dan jasa yang tersedia. Kondisi ini menyebabkan permintaan agregat meningkat, sedangkan penawaran tetap, yang akan terjadi adalah harga akan naik.

3. Teori Struktural : Teori ini menyorot penyebab inflasi dari segi struktural ekonomi yang kaku. Produsen tidak dapat mengantisipasi cepat kenaikan permintaan yang disebabkan oleh pertambahan penduduk. Permintaan sulit dipenuhi ketika ada kenaikan jumlah penduduk.

Secara grafis mengapa inflasi itu terjadi, dapat kita lihat sebagai berikut:

i. Demand Pull Inflation, yaitu inflasi yang disebabkan oleh meningkatnya jumlah permintaan akan barang dan jasa.

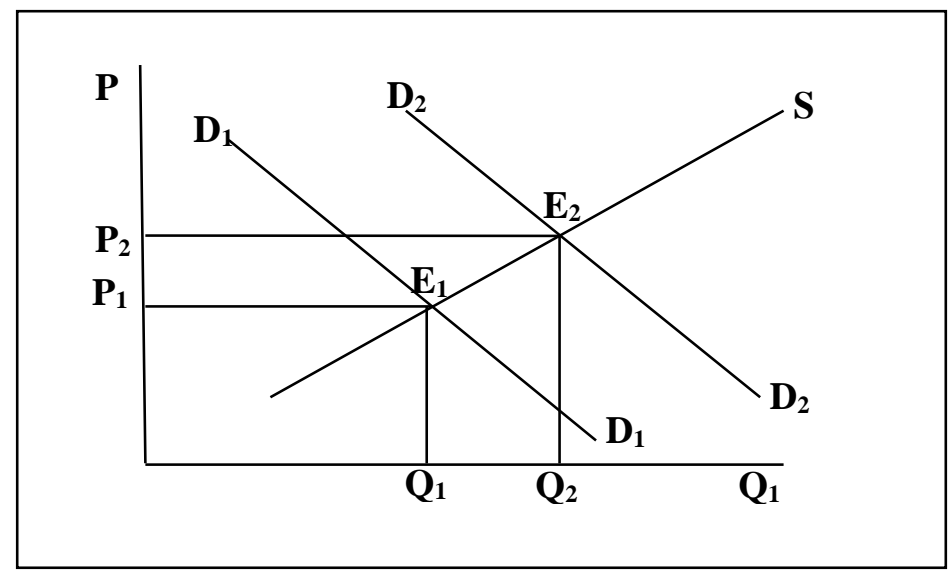

Kurva 1. Demand Pull Inflation

Sumber: Samuelson \& Nordhaus (2009)

Pada kurva di atas menunjukkan hubungan antara harga barang $(\mathrm{P})$, jumlah yang diminta dan ditawarkan (Q), dan keseimbangan harga (E). Terjadinya Demand Pull Inflation ketika permintaan akan barang dan jasa meningkat, maka kurva permintaan total (D) bergeser dari $\mathrm{D}_{1} \mathrm{D}_{1} \mathrm{ke}_{2} \mathrm{D}_{2}$. Ketika itu para pedagang akan mengambil keuntungan dengan menaikkan harga barang dari $\mathrm{P}_{1} \mathrm{ke}_{2}$. Sehingga pada saat itu, terjadi inflasi dan menimbulkan harga keseimbangan baru dari $\mathrm{E}_{1} \mathrm{ke} \mathrm{E}_{2}$. 
ii. Cost Push Inflation, yaitu inflasi yang disebabkan oleh kenaikan biaya produksi.

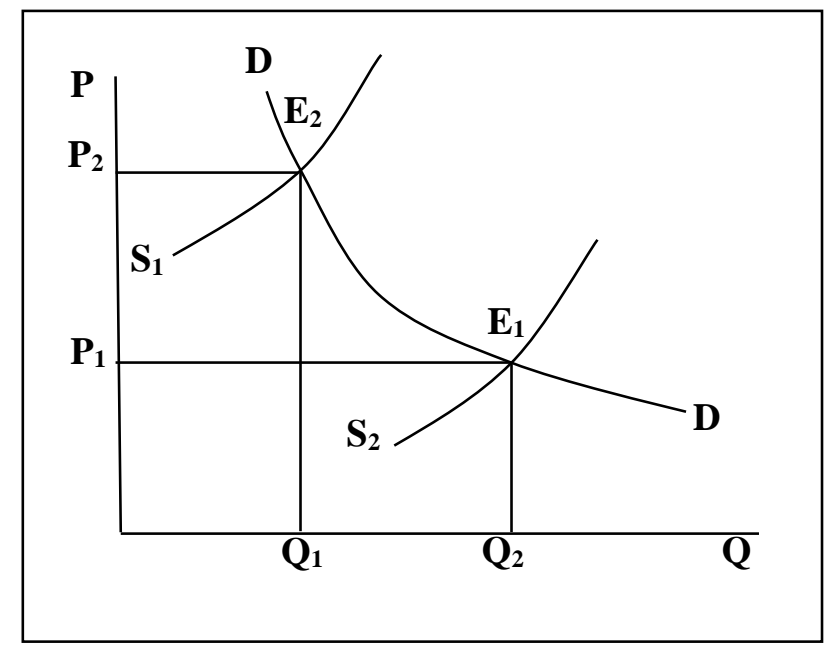

Kurva 2. Cost Push Inflation

Sumber: Samuelson \& Nordhaus (2009)

Pada kurva tersebut menunjukkan perilaku produsen ketika menghadapi situasi dimana harga produksi mengalami peningkatan. Jika terjadi kenaikan harga produksi maka produsen akan menaikkan harga dari $\mathrm{P}_{1}$ ke $\mathrm{P}_{2}$ tetapi dia justru akan menurunkan jumlah barang/jasa yang dihasilkan dari $\mathrm{Q}_{2} \mathrm{ke} \mathrm{Q}_{1}$ sehingga akan menggeser kurva penawaran dari $S_{1}$ menjadi $S_{2}$. Hal ini dilakukan agar produsen tidak terus merugi sambil menunggu harga produksi kembali turun.

Namun demikian, menurut Mankiw (2003), keeratan hubungan inflasi dengan jumlah uang beredar tidak dapat dilihat dalam jangka pendek. Teori inflasi ini bekerja paling baik dalam jangka panjang, bukan dalam jangka pendek. Dengan demikian, hubungan antara jumlah uang beredar dan inflasi dalam data bulanan tidak akan seerat hubungan keduanya jika dilihat selama periode 10tahun.

\subsection{Jumlah Uang Beredar}

Kebijakan moneter adalah instrumen yang sering digunakan oleh otoritas otoritas moneter untuk mempengaruhi kondisi makroekonomi yang dilaksanakan melalui pasar uang (Boediono, 2013:96). Secara khusus, kebijakan moneter bisa diartikan sebagai tindakan yang dilakukan oleh otorita moneter untuk mempengaruhi jumlah uang beredar dan dapat mempengaruhi kegiatan ekonomi suatu negara (Nopirin, 2014: 45).

Total stok uang dalam suatu kegiatan perekonomian dalam satu periode tertentu yang umumnya satu tahun sering disebut sebagai Jumlah Uang Beredar/JUB (money supply). Jumlah uang beredar ini bukanlah hanya uang yang beredar di tangan 
masyarakat saja, tetapi juga adalah uang yang dikeluarkan secara resmi oleh Bank Sentral maupun bank umum (Pracoyo, Kunawangsih dan Antyo, 2005:139).

1. Teori Kuantitas.

Model Klasik tentang uang sering disebut sebagai teori kuantitas, yang mempunyai hubugngan dengan tingkat harga absolut yang ditentukan oleh penawaran uang nominal. Teori ini menyimpulkan bahwa tingkat harga merupakan akibat utama adanya perubahan jumlah uang beredar (Mankiw, 2006: 114).

2. Teori Keynes.

Dalam Nopirin (2014:94), Bahwa Keynes tidak melihat Jumlah uang beredar merupakan faktor eksogen dalam kegiatan suatu perekonomian. Menurut Keynes, uang beredar sebagai faktor yang sangat ditentukan oleh kegiatan ekonomi suatu masyarakat. Jadi menurut Keynes besarnya angaka pelipat uang dipengaruhi oleh kegiatan ekonomi.

3. Teori Kaum Monetaris.

Menurut pandangan kaum Monetaris, bahwa perubahan jumlah uang beredar tidak terpengaruh oleh kegiatan ekonomi, Sehingga jumlah uang beredar merupakan faktor eksogen (Nopirin, 2014:94). Konsep ini berbeda dengan pandangan Keynes. Sehingga kaum moneteris, Milton Friedman menganggap bahwa uang beredar sangat mempengaruhi dan berperan aktif dalam kegiatan ekonomi suatu masyarakat.

Berdasarkan uraian tersebut diatas, bahwa eksistensi jumlah uang beredar dalam perekonomian harus selalu stabil, artinya fluktuasinya harus tetap terjaga, karena dapat mempengaruhi tingkat inflasi.

Penelitian mengenai hubungan antara jumlah uang beredar dan inflasi di Indonesia pernah dilakukan oleh Dumairy (1986) dan Djanin (1990), yang melakukan pengujian terhadap kausalitas antara jumlah uang beredar dan tingkat inflasi di Indonesia. Dengan menggunakan data kwartalan, hasil yang diperoleh secara statistik menunjukkan bahwa jumlah uang beredar mempunyai pengaruh yang lebih signifikan pada inflasi. Dalam penelitian tersebut Dumairy hanya melakukan uji Granger. Sedangkan Janin menggunakan uji Sims, dengan data kwartalan, diperoleh kesimpulan bahwa jumlah uang beredar mempunyai pengaruh yang lebih signifikan pada inflasi.

Widiastuti (2012), meneliti tentang Pengaruh Jumlah Uang Beredar terhadap Inflasi di Indonesia, data bulanan periode Januari 2001-Desember 2011, model yang digunakan Error Correction Models (ECM). Temuannya adalah 1). Dalam jangka pendek jumlah uang beredar tidak berpengaruh atau tidak signifikan terhadap laju inflasi di Indonesia, tetapi inflasi pada bulan tersebut dipengaruhi oleh jumlah uang beredar pada bulan sebelumnya. 2). Dalam jangka panjang panjang jumlah uang beredar tidak berpengaruh atau tidak signifikan terhadap inflasi. 
Putra \& Meydianawati (2014), melakukan penelitian yang berjudul Vector Auto Regressive Terhadap Kausalitas Inflasi dan Jumlah Uang Beredar di Indonesia. Hasil pengujian menunjukkan bahwa Hubungan kausalitas antara tingkat Inflasi dan jumlah uang beredar di Indonesia tidak terdapat hubungan dalam periode penelitian tersebut.

Penelitian ini menggunakan pendekatan metode kuantitatif, yaitu berusaha menjelaskan hubungan satu variabel dengan variabel yang lain, hubungan tersebut dalam bentuk kausalitas, artinya variabel yang satu yaitu jumlah uang beredar dapat mempengaruhi variabel lain yaitu tingkat inflasi atau sebaliknya dan dilanjutkan dengan pengujian hipotesis, yang dapat digambarkan sebagai berikut :

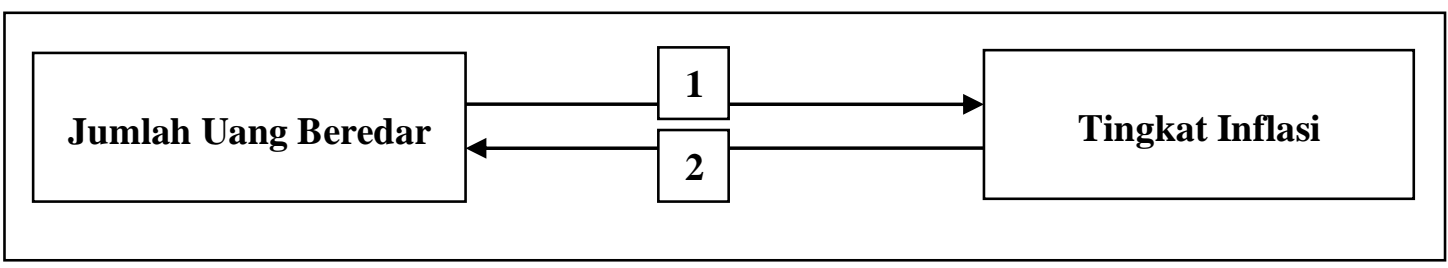

Gambar 1. Model Penelitian

Hipotesa:

1. Diduga jumlah uang beredar mempengaruhi inflasi di Indonesia

2. Diduga inflasi mempengaruhi jumlah uang beredar di Indonesia

\section{METODA PENELITIAN}

Variabel dalam penelitian ini adalah jumlah uang beredar dengan satuan rupiah dan tingkat Inflasi diukur berdasarkan persen. Dengan menggunakan data sekunder kuartalan pada kurun waktu tahun 2000.1-2014.4. Data bersumber dari publikasi Statistik Ekonomi Keuangan Indonesia Bank Indoenesia (SEKI) dari beberapa edisi.

Metode analisis yang akan digunakan dalam penelitian ini adalah:

\subsection{Uji Granger (Granger Causality)}

Pada penelitian ini untuk menganalisis hubungan yang sebenarnya antara jumlah uang beredar dan tingkat inflasi, peneliti menggunakan uji kausalitas, dengan teknik Granger Causality, yang merupakan suatu metode yang sering digunakan untuk mengetahui apakah suatu variabel dependen dapat dipengaruhi oleh variabel independen atau disisi lain variabel independen tersebut dapat bertindak sebagai variabel dependen. Perilaku seperti ini sering disebut sebagai hubungan timbal balik atau hubungan kausal.

Teknik Granger causality mengestimasi dua buah persamaan dibawah ini, dengan penetapan panjang lag variabel penjelas sebanyak 12 berdasarkan pada penelitian sejenis sebelumnya (Dumairy, 1986) : 
1. $\mathrm{LP}_{\mathrm{t}}=\mathrm{ao}+\operatorname{am} \sum_{\mathrm{m}=1} \mathrm{~B}^{\mathrm{m}} \mathrm{LP} \mathrm{P}_{\mathrm{t}}+\mathrm{b}_{\mathrm{n}} \sum_{\mathrm{n}=1} \mathrm{~B}^{\mathrm{n}} \mathrm{LM}_{\mathrm{t}}$

$12 \quad 12$

2. $\mathrm{LM}_{\mathrm{t}}=\mathrm{co}+\mathrm{cm}_{\mathrm{m}=1} \mathrm{~B}^{\mathrm{m}} \mathrm{LM}_{\mathrm{t}}+\mathrm{d}_{\mathrm{n}} \sum_{\mathrm{n}=1} \mathrm{~B}^{\mathrm{n}} \mathrm{LP}_{\mathrm{t}}$

di mana : $\mathrm{LM}_{\mathrm{t}}=\log \left(\mathrm{M}_{\mathrm{t}}\right), \mathrm{LP}_{\mathrm{t}}=\log \left(\mathrm{P}_{\mathrm{t}}\right), \mathrm{M}_{\mathrm{t}}$ adalah jumlah uang beredar dan $\mathrm{P}_{\mathrm{t}}$ adalah tingkat inflasi serta $t$ menunjukkan waktu. Selanjutnya diestimasi pula dua persamaan tersebut yang diberi kendala, dengan mengurangi jumlah lag variabel penjelas, yaitu:

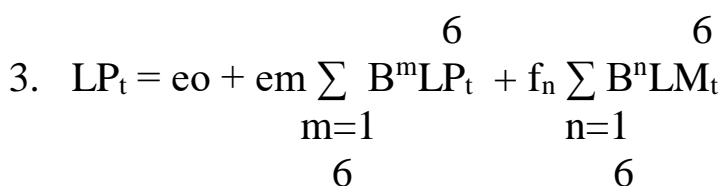

4. $\mathrm{LM}_{\mathrm{t}}=\mathrm{go}+\mathrm{gm} \sum \mathrm{B}^{\mathrm{m}} \mathrm{LM}_{\mathrm{t}}+\mathrm{h}_{\mathrm{n}} \sum \mathrm{B}^{\mathrm{n}} \mathrm{LP} \mathrm{P}_{\mathrm{t}}$ $\mathrm{m}=1 \quad \mathrm{n}=1$

di mana : $\mathrm{LM}_{\mathrm{t}}=\log \left(\mathrm{M}_{\mathrm{t}}\right), \mathrm{LP}_{\mathrm{t}}=\log \left(\mathrm{P}_{\mathrm{t}}\right), \mathrm{M}_{\mathrm{t}}$ adalah jumlah uang beredar dan $\mathrm{P}_{\mathrm{t}}$ adalah tingkat inflasi serta $t$ menunjukkan waktu.

Pada setiap data time series, umumnya sering terjadi hubungan korelasi yang langsung, hal ini dikarenakan struktur data yang tidak stasioner dan tidak terkointegrasi. Sehingga pada penelitian ini dalam Granger Causality test dilakukan tahapan sebagai berikut:

i. Uji Stasioner adalah uji kestabilan data terhadap variabel jumlah uang beredar dan variabel tingkat inflasi. Pengujian ini dimaksudkan untuk mengetahui apakah koefisien tertentu dari model otoregresif yang ditaksir memiliki nilai lebih dari satu atau tidak (dalam nilai absolut), dengan menggunakan uji unit root Dickey-Fuller. Jika di dalam pengujian tersebut ternyata data sudah stasioner, maka pengujian dapat dilanjutkan ke Granger Causality test pada data asli. Tapi jika salah satu variabel ada yang tidak stasioner, maka akan dilakukan pengujian untuk mengetahui apakah kedua variabel terkointegrasi atau tidak.

ii. Jika kedua variabel terkointegrasi, maka dapat langsung dilakukan Granger Causality test pada data asli. Tetapi tidak terkointegrasi, maka data yang tidak stasioner akan distasionerkan pada derajad 1 (first difference) baru dilanjutkan dengan Granger Causality test terhadap data yang stasioner. 
iii. Koefisien tersebut mempunyai nilai sama dengan atau kurang dari satu maka data tersebut tidak stasioner. Proses yang dilakukan untuk pengujian akar-akar unit ini adalah menaksir model otoregresif dari masing-masing variabel akan digunakan dalam studi dengan menggunakan OLS (Dickey \& Fuller, 1979: 1981):

$$
\begin{aligned}
& \text { 1. } D X_{t}=a_{0}+a_{1} B X_{t} \sum_{i+1}^{k} b_{i} B^{i} D X_{t} \\
& \text { 2. } D X_{t}=c_{0}+c_{1} T+c B X_{t}+\sum_{i=1}^{k} d_{i} B^{i} D X_{t}
\end{aligned}
$$

di mana $\mathrm{DX}_{\mathrm{t}}=\mathrm{x}_{\mathrm{t}}-\mathrm{x}_{\mathrm{t}-1}, \mathrm{BX}_{\mathrm{t}}=\mathrm{X}_{\mathrm{t}-1}, \mathrm{~T}=$ Trend waktu dan $\mathrm{X}_{\mathrm{t}}=$ variabel yang diamati pada periode $\mathrm{t}$ serta $\mathrm{B}$ adalah operasi kelambanan waktu ke udik (backward lag operator).

Proses selanjutnya adalah menghitung nilai statistik DF (Dicky Fuller) dan ADF (Augmented Dicky Fuller). Nilai DF dan ADF unuk menguji hipotesis bahwa $\mathrm{a}_{1}=0$ dan $\mathrm{c}_{2}=0$ yang ditunjukkan oleh nisbah $\mathrm{t}$ pada koefisien regresi $\mathrm{BX}_{\mathrm{t}}$. Besarnya time lag $\mathrm{k}$ ditentukan oleh $\mathrm{k}=\mathrm{N}^{1 / 3}$, dimana $\mathrm{N}$ adalah jumlah pengamatan. Nilai kritis statistik DF (ADF) pada derajat $5 \%$ untuk $\mathrm{n}=50$ adalah $(-2,93$ dan $-2,89)$ dan $\mathrm{N}=100$, adalah $(-3,50$ dan $-3,45)$.

\subsection{Uji Kointergrasi (Johansen)}

Sering dijumpai bahwa dua variabel random yang masing-masing merupakan random walk (tidak stasioner), tetapi kombinasi linier antara dua variabel tersebut merupakan time series yang stasioner. Dalam penelitian ini yang digunakan adalah uji yang dikembangkan Johansen untuk menentukan kointegrasi sejumlah variabel (vektor). Jika variabel gangguan ternyata tidak mengandung akar unit atau dikatakan data stasioner maka variabel yang diteliti adalah terkointegrasi yang berarti mempunyai hubungan jangka panjang. Kointegrasi hanya bisa dilakukan ketika data yang digunakan dalam penelitian berintegrasi pada derajat yang sama (Widarjono, 2009). Prosesnya pengujian sebagai berikut:

Hipotesis :

$\mathrm{H}_{0}=$ Tidak terdapat hubungan jangka panjang antara variabel independen dan variabel dependen.

$\mathrm{H}_{1}=$ Terdapat hubungan jangka panjang antara variabel independen dan variabel dependen. 
Kriteria :

Jika nilai trace statistic > nilai critical value maka $\mathrm{H}_{0}$ ditolak

Jika nilai trace statistic < nilai critical value maka $\mathrm{H}_{0}$ diterima

\section{HASIL PENELITIAN DAN PEMBAHASAN}

\subsection{Hasil Uji Akar-akar unit (Unit root test)}

Pengujian Uji Akar-akar unit (Unit roots test) pada dasarnya adalah untuk membuat sebuah struktur data tersebut stasioner, maksudnya adalah data Tingkat Inflasi (IF) dan Tingkat Jumlah Uang Beredar telah stasioner. Uji ini dilakukan sesungguhnya adalah untuk supaya data yang akan digunakan memiliki fluktuasi data yang rendah, sehingga membuat hasil estimasi yang dilakukan memiliki varian yang rendah juga.

Pengujian stasioner data tersebut menggunakan Augmented Dickey Fuller (ADF). Pada tabel 1. dapat dilihat bahwa hasil estimasi uji $A D F$ adalah sebesar -1,7217, sedangkan nilai kritis lebih kecil darinya. Dengan demikian tidak mempunyai cukup bukti untuk menolak hipotesis, sehingga dapat disimpulkan bahwa data menghadapi masalah unit root atau data tidak stasioner, walaupun dengan mengubah panjang lag nya $=12$ atau lag $=6$.

Tabel 1

Pengujian Unit Roots Variabel Inflasi

Pada Tingkat Level

\begin{tabular}{lll}
\hline $\begin{array}{l}\text { Augmented Dickey-Fuller test statistic } \\
\text { Test critical values: } \quad \text { 1\% level }\end{array}$ & -1.721750 & 0.4152 \\
\hline \multicolumn{1}{c}{ 5\% level } & -3.546099 & \\
\hline 10\% level & -2.911730 & \\
\hline Augmented Dickey-Fuller Test Equation & -2.593551 \\
\hline Dependent Variable: D(IF) & \\
\hline Sample (adjusted): 2000Q2 2014Q4 & \\
\hline Included observations: 59 after adjustments
\end{tabular}

Untuk mendapatkan data stasioner, maka perlu dilakukan uji akar-akar unit yang lebih tinggi, yaitu pada tingkat level 1 (first difference), sehingga diperoleh data yang stasioner pada derajat yang sama. Hasil pengujian unit root ini diperoleh nilai sebesar 8,764 , sedangkan nilai kritis lebih besar darinya, yang berarti variabel tingkat inflasi sudah stasioner pada derajat first difference seperti terlihat pada tabel 2. 
Tabel 2

Pengujian Unit Roots Variabel Inflasi

Pada Tingkat First Difference

\begin{tabular}{lll}
\hline \begin{tabular}{l} 
Augmented Dickey-Fuller test statistic \\
\hline Test critical values: $\quad$ 1\% level
\end{tabular} & -8.764295 & 0.0000 \\
\hline \multicolumn{1}{c}{ 5\% level } & -3.548208 & \\
\hline *MacKinnon (1996) one-sided p-values. & -2.912631 \\
\hline Augmented Dickey-Fuller Test Equation & -2.594027 \\
\hline Dependent Variable: D(IF,2) \\
\hline Method: Least Squares \\
\hline Sample (adjusted): 2000Q3 2014Q4 \\
\hline Included observations: 58 after adjustments \\
\hline
\end{tabular}

Berikut ini pengujian terhadap Jumlah Uang Beredar, dari hasil estimasi uji $A D F$ menunjukkan sebesar -1,0599, sedangkan nilai kritis lebih kecil darinya. Kondisi ini menunjukkan tidak mempunyai cukup bukti untuk menolak hipotesis, sehingga dapat disimpulkan bahwa data menghadapi masalah unit root atau data tidak stasioner, seperti terlihat pada tabel 3 .

Tabel 3

Pengujian Unit Roots Variabel Jumlah Uang Beredar Pada Tingkat Level

\begin{tabular}{|c|c|c|c|}
\hline Augmen & ey-Fuller test statistic & -1.059946 & 0.7255 \\
\hline \multirow{3}{*}{ Test critical values: } & $1 \%$ level & -3.550396 & \\
\hline & $5 \%$ level & -2.913549 & \\
\hline & $10 \%$ level & -2.594521 & \\
\hline \multicolumn{4}{|c|}{ *MacKinnon (1996) one-sided p-values. } \\
\hline \multicolumn{4}{|c|}{ Augmented Dickey-Fuller Test Equation } \\
\hline \multicolumn{4}{|c|}{ Dependent Variable: D(JUB) } \\
\hline \multicolumn{4}{|c|}{ Method: Least Squares } \\
\hline \multicolumn{4}{|c|}{ Sample (adjusted): 2000Q4 2014Q4 } \\
\hline Included observa & after adjustments & & \\
\hline
\end{tabular}

Berdasarkan hasil estimasi tersebut, maka perlu dilakukan uji akar-akar unit yang lebih tinggi, yaitu pada tingkat level 1 (first difference), sehingga diperoleh data yang stasioner pada derajat yang sama. Hasil pengujian unit root ini diperoleh nilai sebesar 8,9071, sedangkan nilai kritis lebih besar darinya, yang berarti variabel Jumlah Uang Beredar sudah stasioner pada derajat first difference seperti terlihat pada tabel 4. 
Tabel 4

Pengujian Unit Roots Variabel Jumlah Uang Beredar

Pada tingkat first difference

\begin{tabular}{|c|c|c|c|}
\hline \multicolumn{2}{|c|}{ Augmented Dickey-Fuller test statistic } & -8.907104 & 0.0000 \\
\hline \multirow[t]{3}{*}{ Test critical values: } & $1 \%$ level & -3.550396 & \\
\hline & $5 \%$ level & -2.913549 & \\
\hline & $10 \%$ level & -2.594521 & \\
\hline \multicolumn{4}{|c|}{ *MacKinnon (1996) one-sided p-values. } \\
\hline \multicolumn{4}{|c|}{ Augmented Dickey-Fuller Test Equation } \\
\hline \multicolumn{4}{|c|}{ Dependent Variable: D(JUB,2) } \\
\hline \multicolumn{4}{|c|}{ Method: Least Squares } \\
\hline \multicolumn{4}{|c|}{ Sample (adjusted): 2000Q4 2014Q4 } \\
\hline Included observa & is: 57 after adjustmen & & \\
\hline
\end{tabular}

Berdasarkan hasil pengujian unit root, maka diperoleh bahwa variabel tingkat inflasi dan jumlah uang uang beredar di indonesia pada periode 2000.1 sampai 2014.4 baru stasioner pada first difference.

\subsection{Granger Causality Test}

Selanjutnya adalah pengujian granger causality, dalam pengujian ini penulis ingin mengetahui hubungan yang sebenarnya, maksudnya apakah tingkat inflasi mempengaruhi jumlah uang yang beredar atau sebaliknya. Dengan teknik Granger causality penulis mengestimasi dua buah persamaan, sebelumnya dijelaskan dalam metode penelitian dengan penetapan panjang lag variabel penjelas sebanyak 6 dan 12, apabila probalibilitas terhadap kedua variabel tersebut lebih kecil dari nilai kesalahan yang dapat ditolerir $(\alpha=0,05)$, maka kondisi ini menunjukkan terdapat hubugan kausalitas antara variabel inflasi dan jumlah uang beredar, tetapi apabila salah satu variabel dengan nilai probabilitas lebih besar dari $\alpha=0,05$, maka hubungan kausalitas tidak terjadi.

\subsection{Granger Causality Tests Pada Lags: 6}

Hasil estimasi uji Granger Causality dapat dilihat pada tabel 5 dengan lag 6, menunjukkan bahwa jumlah uang beredar di Indonesia tidak berpengaruh terhadap tingkat inflasi selama periode penelitian ini, karena nilai Prob Null Hypothesis inflasi $0.9278>0,05$. Sementara itu tingkat inflasi di Indonesia berpengaruh terhadap jumlah uang beredar, hal ini ditunjukkan oleh nilai Prob Null Hypothesis Inflasi pada taraf penerimaan, dimana Inflasi $=0,0001<(\alpha=0,05)$. Oleh karena itu inflasi berpengaruh terhadap jumlah uang beredar dan tidak sebaliknya. Ini berarti tidak terdapat hubungan kausalitas antara jumlah uang beredar dan inflasi di indonesia selama periode 2000.1 2014.4. 
Hasil penelitian ini mendukung Model Klasik dengan teori kuantitasnya, yang menyimpulkan bahwa tingkat harga merupakan akibat utama adanya perubahan jumlah uang beredar.

Tabel 5

Pairwise Granger Causality Tests

Pada Lags: 6

\begin{tabular}{|c|c|c|c|}
\hline Pairwise Granger Causality Tests & & & \\
\hline Sample: 2000Q1 2014Q4 & & & \\
\hline Lags: 6 & & & \\
\hline Null Hypothesis: & Obs & F-Statistic & Prob. \\
\hline JUB does not Granger Cause IF & 54 & 0.31064 & 0.9278 \\
\hline IF does not Granger Cause JUB & & 6.26333 & 0.0001 \\
\hline
\end{tabular}

\subsection{Granger Causality Tests Pada Lags: 12}

Sedangkan hasil estimasi uji granger causality pada tabel 6 dengan lag 12, menunjukkan bahwa jumlah uang beredar di Indonesia berpengaruh terhadap tingkat inflasi selama periode penelitian ini, karena nilai Prob Null Hypothesis jumlah uang beredar jatuh pada taraf penerimaan yaitu JUB $0,0062<0,05$. Kondisi yang sama juga ditunjukkan oleh varabel inflasi, dimana nilai Prob Null Hypothesis inflasi berpengaruh terhadap jumlah uang beredar, yaitu Inflasi $=0,0031<(\alpha=0,05)$. Jadi hasil estimasi dengan menggunakan lag yang lebih panjang ( lag = 12 ) menunjukkan terdapat hubungan kausalitas antar variabel penelitian.

Tabel 6

Pairwise Granger Causality Tests

Pada Lags: 12

\begin{tabular}{lccc}
\hline Pairwise Granger Causality Tests & & & \\
\hline Sample: 2000Q1 2014Q4 & & & \\
\hline Lags: 12 & Obs & F-Statistic & Prob. \\
\hline Null Hypothesis: & 48 & 3.34887 & 0.0062 \\
\hline JUB does not Granger Cause IF & & 3.76528 & 0.0031 \\
\hline IF does not Granger Cause JUB & & &
\end{tabular}

\subsection{Uji Kointegrasi Johansen}

Uji kointegrasi yang dikembangkan Johansen untuk menentukan kointegrasi sejumlah variabel (vektor). Jika variabel gangguan ternyata tidak mengandung akar unit atau dikatakan data stasioner maka variabel yang diteliti adalah terkointegrasi yang berarti mempunyai hubungan jangka panjang. Hasil pengujian kointegrasi dapat dilihat pada tabel 7 berikut ini: 
Tabel 7

Hasil Uji Regresi Kointegrasi Johansen

\begin{tabular}{|c|c|c|c|c|}
\hline \multicolumn{5}{|c|}{ Unrestricted Cointegration Rank Test (Trace) } \\
\hline \multicolumn{2}{|l|}{ Hypothesized } & Trace & \multicolumn{2}{|l|}{0.05} \\
\hline No. of CE(s) & Eigenvalue & Statistic & Critical Value & Prob.** \\
\hline None $*$ & 1.000000 & 2135.608 & 15.49471 & 1.0000 \\
\hline At most $1 *$ & 0.080598 & 4.873850 & 3.841466 & 0.0273 \\
\hline \multicolumn{5}{|c|}{ Trace test indicates 2 cointegrating eqn(s) at the 0.05 level } \\
\hline \multicolumn{5}{|c|}{$*$ denotes rejection of the hypothesis at the 0.05 level } \\
\hline \multicolumn{5}{|c|}{ **MacKinnon-Haug-Michelis (1999) p-values } \\
\hline \multicolumn{5}{|c|}{ Unrestricted Cointegration Rank Test (Maximum Eigenvalue) } \\
\hline Hypothesized & & Max-Eigen & 0.05 & \\
\hline No. of CE(s) & Eigenvalue & Statistic & Critical Value & Prob.** \\
\hline None * & 1.000000 & 2130.734 & 14.26460 & 1.0000 \\
\hline At most $1 *$ & 0.080598 & 4.873850 & 3.841466 & 0.0273 \\
\hline
\end{tabular}

Hasil uji kointegrasi diperoleh bahwa nilai trace statistic sebesar 2135.608> critical value sebesar 15.49471, begitu juga dengan nilai max eige stat sebesar $2130.734>14.26460$. ini berarti bahwa variabel yang sedang diamati dalam penelitian ini saling berkointegrasi atau memiliki hubungan jangka panjang. Hasil penelitian ini mendukung Model Klasik dengan teori kuantitasnya, yang menyimpulkan bahwa tingkat harga merupakan akibat utama adanya perubahan jumlah uang beredar.

\section{SIMPULAN}

Beberapa catatan yang dapat ditarik dari hasil penelitian ini mengenai hubungan inflasi dan jumlah uang beredar selama periode penelitian 20001.1-2014.4 adalah sebagai berikut: bahwa data dalam penelitian ini menghadapi masalah unit root atau data tidak stasioner, baik terhadap variabel Tingkat Inflasi maupun Jumlah uang beredar, dan setelah dilakukan pengujian lebih lanjut, ternyata data sudah stasioner pada tingkat level 1 (first difference).

Hasil estimasi uji Granger Causality dengan lag 6, menunjukkan bahwa jumlah uang beredar di Indonesia tidak berpengaruh terhadap tingkat inflasi, namun tingkat inflasi di Indonesia berpengaruh terhadap jumlah uang beredar selama periode 2000.1 2014.4. Sedangkan hasil estimasi uji Granger Causality dengan lag 12, menunjukkan bahwa jumlah uang beredar di Indonesia berpengaruh terhadap tingkat inflasi dan sebaliknya. Kondisi ini menunjukkan bahwa terdapat kausalitas antara jumlah uang beredar dan inflasi selama periode 2000.1 -20014.4.

Hasil uji kointegrasi diperoleh bahwa Jumlah Uang Beredar dan Tingkat Inflasi, variabel saling berkointegrasi artinya kedua variabel memiliki hubungan jangka panjang. 
Mengacu kepada hasil yang diperoleh dari penelitian ini, maka untuk jangka pendek sebaiknya kebijakan moneter yang dapat dilakukan Bank Sentral adalah dengan mengendalikan jumlah uang yang beredar, sehingga tingkat inflasi dapat stabil. Riset ini akan lebih baik jika dilanjutkan dengan menganalisis tingkat inflasi, oleh karenanya bagi peneliti lanjutan, mengembangkan model inflasi sangat diharapkan.

\section{UCAPAN TERIMA KASIH}

Penulis mengucapkan terima kasih kepada Pimpinan Fakultas Ekonomi dan Bisnis Universitas Tanjungpura (FEB UNTAN) yang telah membiayai riset ini dan pihak-pihak terkait yang telah memberikan dukungan terlaksananya kegiatan penelitian.

\section{DAFTAR PUSTAKA}

Boediono. ( 2000). Ekonomi Moneter. Edisi 3. Yogyakarta: BPFE.

Boediono. (2013). Ekonomi Makro. Yogyakarta: BPFE.

Dickey, D., \& Fuller. W. A. (1979). Distribution of the Estimators for Autoregressive Time Series with a unit root, Journal of the American Statistical Assosiation, 74, 401-419.

Dickey, D., \& Fuller. W. A. (1981). Likelihood Ratio Statistic for Autoregressive Time Series with a unit root. Econometrica, 49 (4), 1057-1073.

Djanin, M. A. (1990). Monetary Control In A Developing Countries: Indonesian Case, Disertasi Doktor, Universitas Indonesia, tidak dipublikasikan.

Dumairy. (1986). Money Velocity in Indonesia. Katholike Universiteit Leuven, Belgie. Tidak dipublikasikan.

Dumairy. (1987). Kausalitas Antara Bunga Beredar dan Inflasi di Indonesia, Jurnal Ekonomi dan Bisnis Indonesia (JEBI).

Eagle, R. F., \& Granger, C. W. J. (1987). Co-integration and Error Correction Representation, Estimation and Testing. Econometrica, 55, 251-276.

Granger, C. W. J. (1988). Some Recent Development in A Concept of Causality, Journal of Econometric, 39, 199-211.

Gujarati, D. (1995). Ekonometrika Dasar. Jakarta: Erlangga.

Insukendro. (1993). Ekonomi Uang dan Bank Teori dan Pengalaman di Indonesia, Edisi Pertama, Yogyakarta: BPFE.

Miskhin, S. F. (2010), Ekonomi Uang, Perbankan, dan pasar Keuangan. Buku 1. Edisi 8. Terjemahan. Jakarta: Penerbit Salemba Raya 4. 
Putra, I. K., \& Meydianawati, L. G. (2014). Analisis Vector Auto Regressive Terhadap Kausalitas Inflasi dan Jumlah Uang Beredar di Indonesia. E-Journal Ekonomi Pembangunan Universitas Udaya, 3, 180-189.

Mankiw, N. G. (2003). Teori Makroekonomi Edisi Kelima. Terjemahan. Jakarta: Penerbit Erlangga.

Mankiw, N. G. (2006). Principles of Economics, Pengantar Ekonomi Makro, Edisi Ketiga, Salemba 4. Jakarta.

Nopirin. (2014). Ekonomi Moneter Buku I, Edisi 1, Cetakan 14. Yogyakarta: BPFE.

Pracoyo, T, K., \& Antyo. (2005). Aspek Dasar Ekonomi Makro di Indonesia. Jakarta: Gramedia Widiasarana Indonesia.

Samuelson, P. A., \& Nordhaus. W. D. 2009. Economics. Nineteenth Edition. New York: McGraw-Hill Irwin.

Widarjono, A. (2009). Ekonometrika, Teori dan Aplikasi untuk Ekonomi dan Bisnis. Edisi Kedua. Yogyakarta: Ekonisia.

Widiastuti, I, L. (2012). Pengaruh Jumlah Uang Beredar Terhadap Inflasi Di Indonesia Bulan Januari 2001 - Desember 2011 : Pendekatan Error Correction Model (Ecm). Diakses dari http://e-journal.uajy.ac.id/id/eprint/109 